\title{
WestVirginiaUniversity
}

THE RESEARCH REPOSITORY @ WVU

Graduate Theses, Dissertations, and Problem Reports

2011

\section{West Virginia 4-H Camp Songs and Music Traditions}

Jason A. Burnside

West Virginia University

Follow this and additional works at: https://researchrepository.wvu.edu/etd

\section{Recommended Citation}

Burnside, Jason A., "West Virginia 4-H Camp Songs and Music Traditions" (2011). Graduate Theses, Dissertations, and Problem Reports. 463.

https://researchrepository.wvu.edu/etd/463

This Thesis is protected by copyright and/or related rights. It has been brought to you by the The Research Repository @ WVU with permission from the rights-holder(s). You are free to use this Thesis in any way that is permitted by the copyright and related rights legislation that applies to your use. For other uses you must obtain permission from the rights-holder(s) directly, unless additional rights are indicated by a Creative Commons license in the record and/ or on the work itself. This Thesis has been accepted for inclusion in WVU Graduate Theses, Dissertations, and Problem Reports collection by an authorized administrator of The Research Repository @ WVU. For more information, please contact researchrepository@mail.wvu.edu. 
West Virginia 4-H Camp Songs and Music Traditions

\author{
Jason A. Burnside
}

Thesis submitted to the

Davis College of Agriculture, Natural Resources and Design

at West Virginia University

in partial fulfillment of the requirements

for the degree of

\author{
Master of Science \\ in \\ Agricultural and Extension Education
}

Harry N. Boone, Jr., Ph.D., Chair

Deborah A. Boone, Ph.D.

Lauren Lindsey, M.M.

Division of Resource Management

Morgantown, West Virginia

2011

Keywords: 4-H, Camp Songs, 4-H Camp, Agriculture Education 


\section{ABSTRACT \\ West Virginia 4-H Camp Songs and Music Traditions \\ Jason A. Burnside}

The purpose of this study was to determine the role of music in 4- $\mathrm{H}$ traditions from the beginning of the organization to the present. In addition to the overall 4- $\mathrm{H}$ traditions, the research focused on traditions in the 4-H camping program. The research examined songs, song quality, and the role they played in the 4- $\mathrm{H}$ tradition and/or the 4- $\mathrm{H}$ camp experience. Differences and similarities of 4- $\mathrm{H}$ music from the beginning of the 4H program in West Virginia to the present day were explored. The study also examined the origins of the songs used in the West Virginia 4-H program discerning whether or not it was specifically a 4-H original song or a song originally written for different purposes. The study described songs currently being used and those that are no longer used. 


\section{DEDICATION}

This study is dedicated to the West Virginia 4-H program and its rich music traditions.

"May we be guided by those who came before, and open to that which is yet to come." 


\section{ACKNOWLEDGEMENTS}

I would like to acknowledge and thank my graduate committee for their time, wisdom, and dedication in helping me with this study. Deborah A. Boone, Ph.D., Harry N. Boone, Jr. Ph.D., and Lauren Lindsey M.M. have each helped me succeed in this endeavor and for that I am grateful.

I am very thankful for the support of my family, friends, and colleagues who have supported and encouraged me. 


\section{TABLE OF CONTENTS}

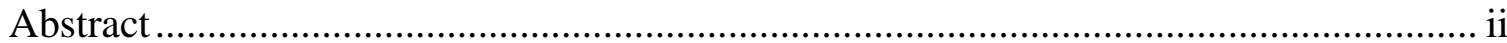

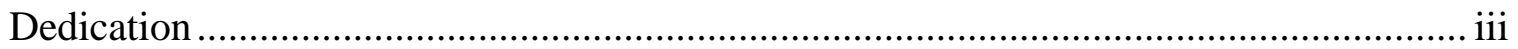

Acknowledgements.............................................................................................. iv

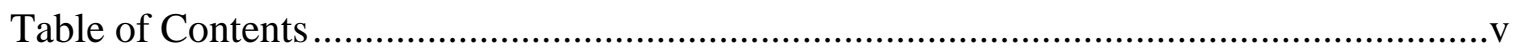

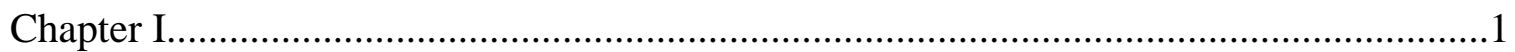

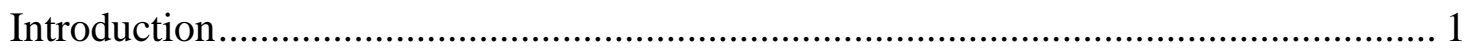

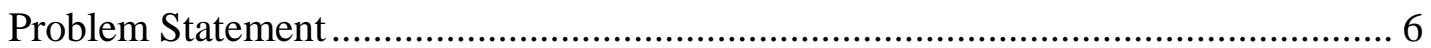

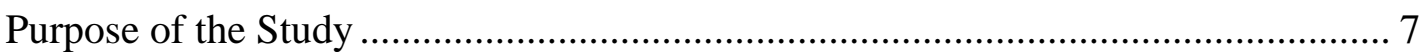

Objectives of the Study ........................................................................................ 7

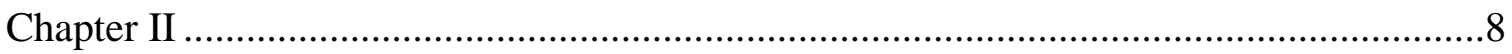

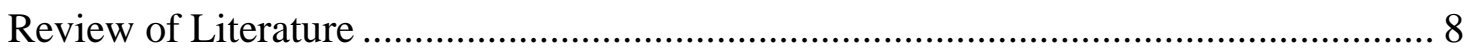

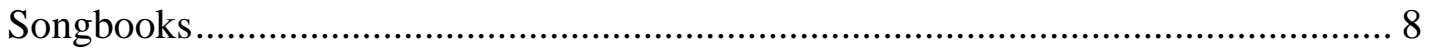

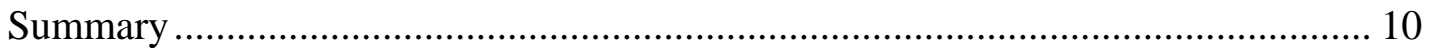

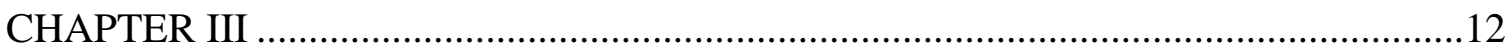

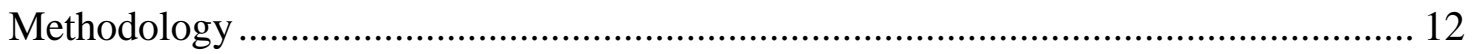

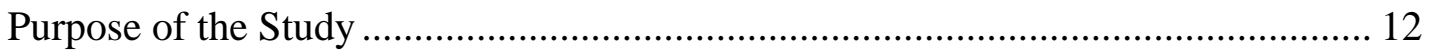

Objectives of the Study ................................................................................... 12

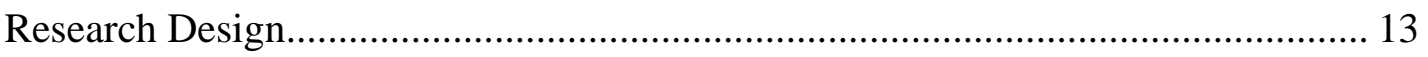

Phase 1: Historical Document Analysis.................................................................. 13

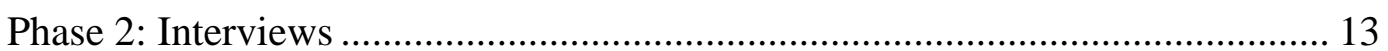

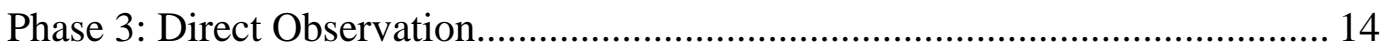

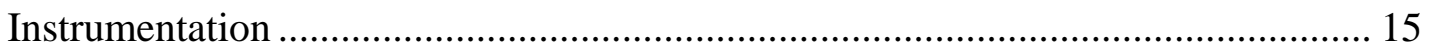

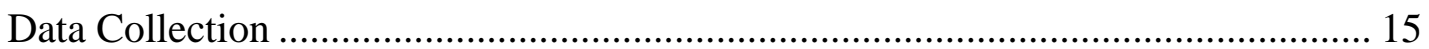

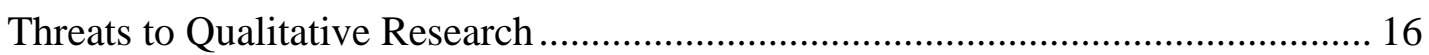

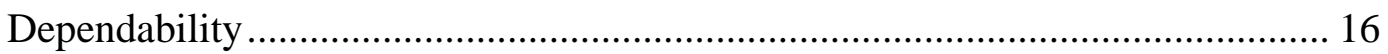

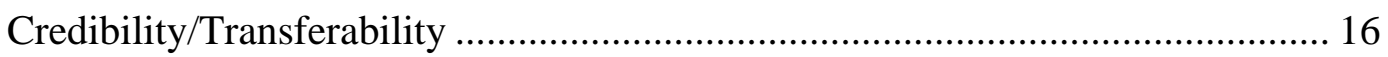

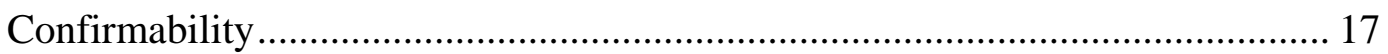

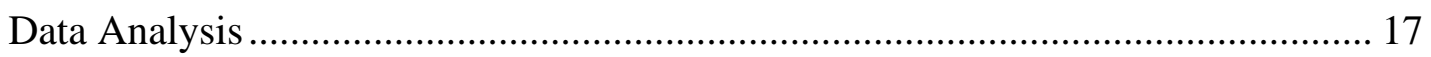

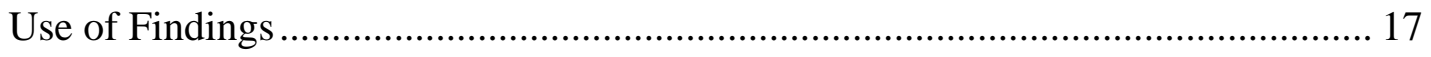

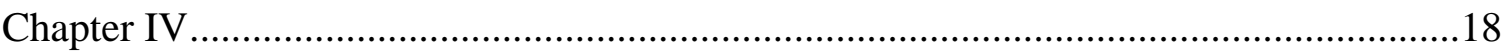

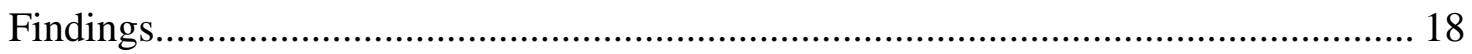

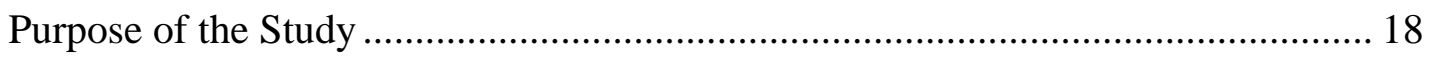

Objectives of the Study ....................................................................................... 18 


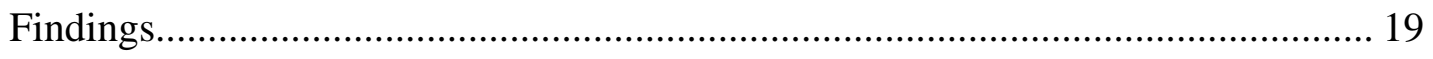

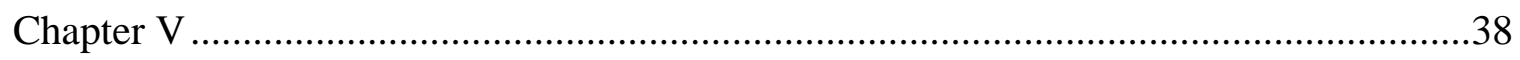

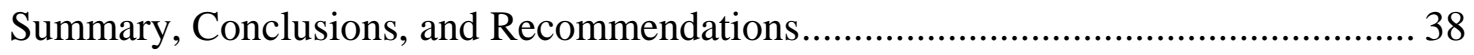

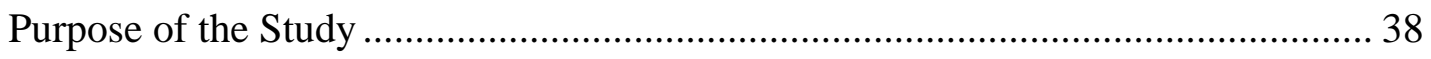

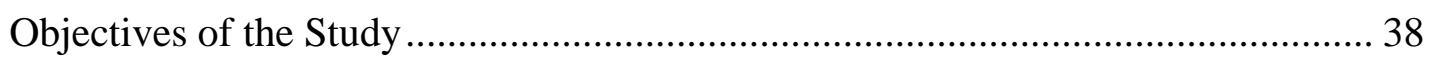

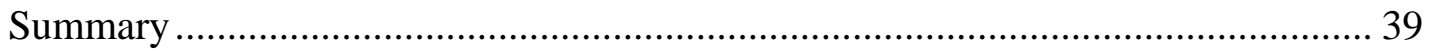

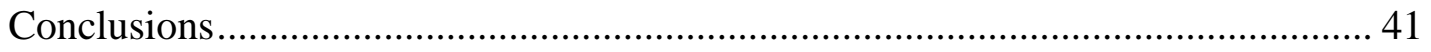

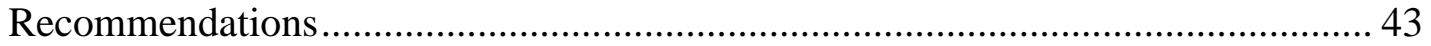

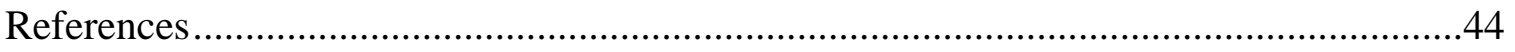

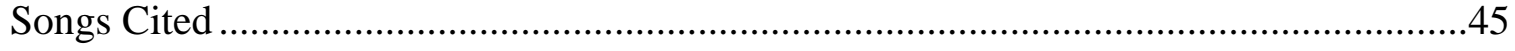

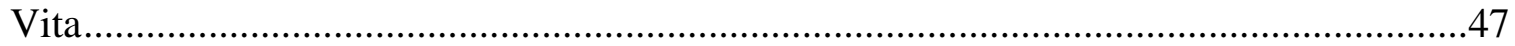




\section{CHAPTER I}

\section{Introduction}

Music has been an integral part of many cultures throughout history (Gibson, 2002). Music has been used to define traditions and religious rites. Music experiences evolve as they pass through time. American music began with the influence of the first settlers from Europe. Hymns and spiritual songs were a part of their society and everyday culture.

Music education has been a part of America's tradition of music development and appreciation for hundreds of years (Thibodeaux, 2011). The history of music in the curriculum of public schools can be traced back to the Revolutionary War (Gibson, 2002). Music education in America was based around learning to sing using a system of written notation found in church hymns. Learning to sing played an integral part in being able to participate in church music.

In the early 1800s, schools began offering music as part of their curriculum. An important leader for music education during this period was Lowell Mason. Mason (1792-1872) is best known as the founder of music education in the American school system. He was widely recognized for composing and arranging many well known hymn tunes and published many influential tune books for a national audience. Mason's work as a pioneer in music education first started at the Boston Academy of Music, which he cofounded in 1833 with George James Webb. (Foundation, 2011) In the mid 1900s, work by composers such as John Phillips Sousa shifted the emphasis in music education from vocal to instrumental study. However, choral music developed rapidly, and in 1961, musicians launched the American Choral Directors Association. Other movements and 
organizations, such as the National Endowment for the Arts and the Ann Arbor Symposium, not only funded music education, but openly discussed teaching methods, music education issues and music impacts (Thibodeaux, 2011). Today, students enjoy a wide range of music education opportunities. They may pursue higher education in performance, education, composition/theory, or production/management. Because of the rise in technology and the popularity of entertainment media, music education has expanded to include electronic/digital music and film scoring, with an emphasis on less tonal melodic and harmonic structure (Thibodeaux, 2011).

Involvement in music is an important aspect of youth development. The comparative gains for arts involved youngsters generally become more pronounced over time. More importantly, this pattern also holds for children from low-income and low parent education level homes. Students who report consistent high levels of involvement in instrumental music over the middle and high school years show significantly higher levels of mathematics proficiency by grade 12. (Catterall, Chapleau, \& Iwanaga, 1999)

Music has a rich history with numerous youth organizations including the Boy Scouts of America and the Girls Scouts of America. Much like 4-H, music has always played a big part in Scouting. Scouts have always enjoyed the fun and fellowship that music can create. Songs are used to open or close meetings, to enhance ceremonies, to lighten a load while hiking, or just to share a special moment with other Girl or Boy Scouts. (Girl Scouts of America, 2011)

The 4-H organization was established in 1902 as part of the United States Department of Agriculture. The organization has grown to its current enrollment of 6,330,612 (National 4-H Council, 2010). 4-H programming is currently offered in all 50 
states as well as many international countries. First organized in 1912 in West Virginia, it is present in all fifty-five counties throughout the state. 4-H originally planned to provide needed life skills and vocational education for youths whose parents could not provide those resources. It was originally conceived as an excellent way to initiate technological change through families. 4-H currently boasts a 100-year history of creative developmental work with youths. Programming has always been delivered in a variety of models (West Virginia University, 2010).

Music has been an integral part of 4-H programming since its inception. 4-H community clubs, awards and recognition ceremonies, 4-H projects, 4-H camps, and various facets of 4-H incorporate music into their programming. Music is used within the 4-H organization in many ways. Traditional songs are used as part of the club curriculum. For example “West Virginia Boys and Girls,” the West Virginia State 4-H song, is often sung before meetings. Songs such as "West Virginia Boys and Girls," “4-H Hymn,” “Plowing,” and “Dreaming” are used throughout the 4-H program as part of club meetings and special programs.

In many states, a camping component is offered as a part of 4-H’s educational programming and youth have been taking advantage of these opportunities since the beginning of the 4-H organization. 4- $\mathrm{H}$ offers various types of residential 4-H camps during the summer for county members. Depending on decisions of the county 4-H agent, staff, and participants the county holds either an all-age camp or separate younger/older camps where the age cutoff is usually around 13. Camps are directed by county Extension agents and volunteer staff. Many camps have a central theme for all the educational programs. 4-H camping has been an intrinsic part of the West Virginia 
4-H program since Camp Good Luck, held in Randolph County in 1915, was the first organized county camp in the United States. By providing a fun learning environment for 4-H members and volunteers, camping remains an important educational delivery method of the 4-H program. (WVU Extension Service, 2003)

Extension Camping Instructors (ECIs) are paid camping instructors trained by West Virginia University to attend county camps. ECIs work closely with the camp directors and staff to lead educational programs and ensure the smooth operation of the 4-H camp. ECIs are trained to lead special programs and music in the camp settings. They are trained as song leaders and practice leading songs before traveling across the state to teach the youth. 4-H song leaders have existed since 4-H camps began. While ECIs have different musical aptitudes, they must be able to lead a successful evening campfire program where singing is a key component.

The evening campfire program is a memorable part of West Virginia 4-H camps. Known as Council Circle, this program brings the entire camp together each evening for games, skits, stories, and singing. Council Circle is a place of energy and enthusiasm for 4-H members. It provides youth with a feeling of spirit, togetherness, and group cohesion. It also offers a chance for youth to excel by sharing hidden talents with fellow campers. Council Circle grants an opportunity for participation by all, ranging from the youngest to the oldest, and the newest to the most experienced camper (WVU Extension Service, 2003).

West Virginia has been a part of this growth in 4-H enrollment including the educational opportunities offered as a part of the camping program. 4-H camps have been held as a part of the 4-H program through the West Virginia Extension Service since 
the first camp in Randolph County in 1914 (Stewart, 1969). Currently 4-H camps are held in all 55 West Virginia counties as well as many state events serving thousands of West Virginia youth. State 4-H camping programs are held at Jackson’s Mill State 4-H Camp near Weston, West Virginia. Jackson’s Mill was specifically chosen by William H. “Teepi” Kendrick, a key founder of 4-H in West Virginia, to be the home state 4-H camp (Stewart, 1969). State 4-H camps included Older Members Conference (OMC) as well as the Alpha I and Alpha II camps. Youth from all 55 counties are able to attend these week long, residential camps. West Virginia State 4-H camps aim to develop leadership, teach new skills, and provide personal development experiences.

The West Virginia 4-H camping program has a rich heritage of music and singing in its camps. In each camp, 4-H camp songs are sung to add to the camp experience and camp moral. Over the years some songs have been removed from the activity, some songs have been changed, and new songs have been added. 4-H songbooks and notation of 4-H songs has changed throughout the history of 4-H. Songbooks also come in many different versions and styles. 4-H song books have been created specifically for state and county 4-H camps. Some songbooks are made with written music notation, some with just words, some are made as a compilation of song titles, and some the combination of all three.

Evening Council Circle programs are fueled by the campers’ participation in singing. Throughout the day, they work together to come up with skits and songs to perform at Council Circle. They join in group singing throughout the day and are led by a song leader around the fire in the evening. Special music is performed at special events and ceremonies for many different camp programs. The culmination of music 
experiences gained by 4-H participants in a camp setting allows youth to experience music at their own level. The principle of Council Circle is borrowed from the Native Americans and is based on their customs. Native Americans took this opportunity to come together, reflect on the day, and set aside their differences. This time also provided a chance for inter-tribal discussions, as well as an opportunity to talk about upcoming issues or activities.

The Council Circle program is an integral educational component of the West Virginia 4-H camping program. The campfire brings a focus to the end of a busy day. The glow of the campfire, surrounded by darkness, helps to create a gradual quietness over almost any gathering of 4-H members. It is the perfect setting for meditation and imagination in songs, stunts, and stories. Council Circle provides a democratic way of arranging a group. Allowing for equalization of responsibility and opportunity, it is an ideal place to teach group spirit and cooperation (WVU Extension Service, 2003).

\section{Problem Statement}

Youth have participated in 4-H and 4-H camps since 1902. Over this time 4-H songs have changed from the original days of $4-\mathrm{H}$ to the present. Songs have been removed from the songbooks and new songs have been created and adopted. The ways songs are notated in 4-H songbooks have changed. Singing abilities and the knowledge of music is different for young people of each generation. To better understand today's 4-H musical traditions, the changes in music and 4-H should be documented. The documentation should also include reasons for the changes. 


\section{Purpose of the Study}

The purpose of this study was to determine the role of music in 4-H traditions from the beginning of the organization to the present. In addition to the overall 4- $\mathrm{H}$ traditions, the research focused on traditions in the 4-H camping program. The research examined songs, song quality, and the role they played in the 4-H tradition and/or the 4-H camp experience. Differences and similarities of 4-H music from the beginning of the 4-H program in West Virginia to the present day were explored. The study also examined the origins of the songs used in the West Virginia 4-H program discerning whether or not it was specifically a 4-H original song or a song originally written for different purposes. The study described songs currently being used and those that are no longer used.

\section{Objectives of the Study}

The objectives of this study are reflected in the following research questions:

1. What songs have been traditionally sung in West Virginia 4-H?

2. Why have songs been dropped from the list of songs preferred?

3. What changes have occurred in how these songs have been documented?

4. What are the origins of the songs sung as a part of the West Virginia 4-H program?

5. What are the perceptions of 4- $\mathrm{H}$ alumni and current members of the quality of songs in West Virginia 4-H?

6. Have songs changed musically from their origin to present day?

7. Are there any controversial issues with any songs in West Virginia 4-H? 


\section{CHAPTER II}

\section{Review of Literature}

\section{Songbooks}

Songbooks have been used to document songs throughout 4-H history. Examples of these songbooks from various time periods and locations have been collected. These song books were used to evaluate how songs have changed based on titles included, written notation and lyrics.

Songbooks used for 4-H camp purposes can be categorized in two general areas. Those that are found in various book forms with written notation compared to those that are simply sheets with song titles and words. Throughout the history of the 4-H camping program in West Virginia many different songbooks have been used. Unfortunately, none of the songbooks have been officially or professionally published.

Counties have developed their own songbooks throughout the years and there is little consistency between the different versions of the songbooks. Inconsistency of songbooks often occur based on changes in the year to year camp music selections. While diversity in many of the county 4-H camps is encouraged, a model such as the West Virginia State 4-H camps including Older Members Conference, Alpha I, and Alpha II could be used. Using state 4-H camps as a model would provide a more consistent example for county 4-H camps to follow.

Formal song books have been produced that include an index, songs with written notation and put together in book form. An example of this type of songbook is West Virginia Sings (1967). It was printed and distributed by West Virginia University to County 4-H programs. It has been available to county 4-H programs since the 1960’s and 
is still used and referenced today. The quality of this song compilation was increased by the addition of written notation to correspond with the words to each song. The volume was printed in small paperback pocket sized books to be easily carried and used in West Virginia 4-H camps. Two printings have taken place with the cover changing color from yellow to blue (West Virginia Sings, 1967).

In the 1930s, the National Committee on Boys and Girls Club Work split up the categories of the 4-H Handy Book and published the National 4-H Club Song Book (1938). It was made available to 4-H clubs through the National 4-H Supply Service. Carrying even more songs, the new Song Book not only had the words to most of the songs, but the printed music, as well. A National 4-H Songbook Committee, headed by R. A. Turner, Field Agent of the Federal Extension Service, directed the production of later editions, selecting the songs to be included, securing copyright clearances, and assuring the Song Book included a well-balanced selection of patriotic songs, religious songs and spirituals, traditional popular songs and 4-H songs. For example, the 1954 revised edition of the National 4-H Club Song Book included the music and words to 80 selections including such songs as "America the Beautiful," "The Star-Spangled Banner," "Battle Hymn of the Republic," "Jacob's Ladder," "Swing Low Sweet Chariot,” "Follow the Gleam," "This is My Father's World," "Now the Day Is Over," "Home on the Range," "Down in the Valley," "Tell Me Why," and "Study War No More.” Some of the traditional 4-H songs of the day were also a prominent part of the book. These songs included "Dreaming," "A Plowing Song," "A Place in the Sun,” "The Pride of the Land," "4-H Field Song," "4-H Ceremonial Song," "and the "National 4-H Pledge Song.” Over 
400,000 copies of the National 4-H Club Song Book were sold during the first decade (National 4-H History Preservation Team, 2011).

The origins of many 4-H songs are found in hymnals and traditional spiritual songs. These songs are used in 4- $\mathrm{H}$ camp because they are known and used in the time period of which their sung.

Participating in a campfire activity is a tradition of many camping programs. In the West Virginia 4-H program the evening campfire activity is called "Council Circle." The purposes of Council Circle are to help bring closure to the day, and to set the tone for the next day's activities. Council Circle brings 4-H members and volunteers together around a campfire to participate with their respective tribe: Cherokee, Delaware, Mingo, Seneca, or Big Feet (WVU Extension Service, 2003). The tribes are simply groups of campers working together throughout the day to participate together as a group for the evening Council Circle.

Each tribe has its own traditional song. These songs are sung as a way to instill pride, tribal spirit, and loyalty. The tribal songs are simple labeled as "Seneca Tribal Song," "Mingo Tribal Song," "Delaware Tribal Song," "Cherokee Tribal Song," and "Big Feet Tribal Song." These songs have been sung by generations of 4-H camp participants.

\section{Summary}

Whether it is a published copy of West Virginia Sings or a copied sheet of paper with song titles, the song books in the 4-H camp setting is the same. Having a reference to use of songs to be sung as part of camp and for various settings is the practical 
application of 4-H song books. They also help to document the songs used at different periods of time throughout the history of the 4-H camping program. 


\section{CHAPTER III}

\section{Methodology}

\section{Purpose of the Study}

The purpose of this study was to determine the role of music in 4- $\mathrm{H}$ traditions from the beginning of the organization to the present. In addition to the overall 4-H tradition, the research focused on traditions in the 4-H camping program. The research will examine songs, song quality, and the role they played in the 4-H tradition and/or the 4-H camp experience. Differences and similarities of 4-H music from the beginning of the 4-H program in West Virginia to the present day were explored. The study also examined the origins of the songs used in the West Virginia 4-H program discerning whether or not it was specifically a 4-H original song or a song originally written for different purposes. The study described songs currently being used and those that are no longer used.

\section{Objectives of the Study}

The objectives of this study are reflected in the following research questions:

1. What songs have been traditionally sung in West Virginia 4-H?

2. Why have songs been dropped from the list of songs preferred?

3. What changes have occurred in how these songs have been documented?

4. What are the origins of the songs sung as a part of the West Virginia 4-H program?

5. What are the perceptions of 4-H Alumni and Current Members of the quality of songs in West Virginia 4-H?

6. Have songs changed musically from their origin to present day? 
7. Are there any controversial issues with any songs in West Virginia 4-H?

\section{Research Design}

A qualitative research design was used that included a combination of historical and document analysis techniques, focus groups, and one-on-one interviews. Historical research analyzes documents and artifacts to gain insight into what has happened in the past (Ary, Jacobs, \& Razavieh, 2006). Content or document analysis is a research method applied to written or visual materials for the purpose of identifying specified characteristics of the material (Ary et al., 2006).

\section{Phase 1: Historical Document Analysis}

The historical analysis phase of the research involved the review of multiple versions of song books used by 4-H members from 1912 to the present. Historically, songs were noted when they were first published and the duration they remained as song books. The 4-H archives at Jackson's Mill State 4-H camp were used to provide historical background of the 4-H program during the time periods examined. The results of the historical phase of the research were confirmed with interviews and focus groups (see Phase 2). Data collected was coded based on items of similarity of time frame and content. Data from these documents was compared to historical events of the time period.

\section{Phase 2: Interviews}

Phase 2 of the data collection involved individual (one-on-one) and group interviews (focus groups). The population for both types of interviews was individuals with a 4-H background who were over the age of 18 . This included current and past 4-H 
Volunteer Leaders, Extension Employees, 4-H Alumni, and current 4-H members over the age of 18.

The researcher worked with camp directors and Extension employees to identify key individuals who met the criteria for inclusion in the study. The researcher attended three State 4-H camps, six county 4-H camps, and two other weekend and specialty camping programs to collect data for this study. Participants were contacted prior to the interview by the researcher. All interviewees were asked to sign a consent form before participating. No interviews were conducted with participants under the age of 18 .

Participants for individual interviews as well as focus groups were selected based on recommendation of county Extension Agents and staff. The location of the interviews varied based on the camp taking place. Interviews lasted between 30 and 60 minutes.

\section{Phase 3: Direct Observation}

The researcher was a non-participant observer at a number of 4-H camps in 2011. This included three State 4-H camps, six county 4-H camps, and two other weekend and specialty camping programs. As a non-participant observer the researcher observed the setting of music being performed, the group, the song(s) being sung, quality of singing, and other distinct features of the event were noted.

A log was kept of all observations. It noted time, place, and setting as well as all observations made. This allowed for an audit trail after all observations were made. The key areas observed were consistent with most 4-H camp settings.

Camp directors collect parental consent forms from all individuals participating in their respective camps. Campers were also asked to sign the WVU media release consent 
form. This form allows their likeness to be used in publications. The researcher was strictly a non-participant observer and had no direct contact with the camp participants.

\section{Instrumentation}

Phase 1 and 3 of the study involved direct observations of materials and individuals. In qualitative studies of this nature, the human investigator is the primary instrument for the collection of data (Ary et al., 2006). The researcher was qualified to make the necessary observations for this study because of his background in the field of music and Music Education as well as 4-H. He earned a Bachelor of Arts degree in Music Education from Alderson-Broaddus College. The researcher has a valid West Virginia Teaching license in K-12 Music Education. The researcher has years of experience as a 4-H Member, Volunteer Leader, Extension Camping Instructor, and Extension Assistant.

In Phase 2 interviewees were asked to expound on their opinions of the status of the 4-H camp music tradition in West Virginia 4-H camps. Questions inquired about individuals past experiences and thoughts as well as their current ideas of the camp music. Follow up questions were asked to probe for in-depth answers and results beyond the basic questions being asked. The results of the interviews and conversations were coded and categorized.

\section{Data Collection}

The researcher kept an accurate record of all observations made for the purpose of analyzing data and providing an audit trail. An accurate log of all research activities was maintained. The study results were triangulated using information obtained from all three phases of the study including the historical document analysis, interviews, and 
observations. The information was recorded using audio and visual recording devices and a written log of observations. The information was coded and analyzed.

\section{Threats to Qualitative Research}

\section{Dependability}

Dependability of a qualitative study is a measure of how similar the data will be if the study was replicated. Two procedures were used to insure the dependability of the study. An audit trail of all the steps and procedures was maintained for the entire study. Data were collected in numerous locations and with multiple groups. After the data were collected it was coded and recoded to increase accuracy. This will aid other researchers in repeating the study in other settings with similar results.

\section{Credibility/Transferability}

Credibility refers to the degree to which the researcher's observations are believable. The background of the researcher is the first step in establishing the research's credibility. The researcher is an expert in the area that was studied. A variety of sources of data were used along with numerous data collection methods. The findings were presented to a panel of experts to "verify" the researcher's interpretations of the data were correct.

Transferability is the degree to which the findings can be applied to other contexts or groups. The participants involved in the study were thoroughly described to allow comparisons to be made with other groups in other locations and times. The results of the research will be transferrable to other groups that have camping programs and sing songs at summer camp. Such groups may include, Boy Scouts, Girl Scouts, YMCA summer camping programs, and various religious groups that hold summer camps. The 
populations for the study were not selected on the basis of their uniqueness, specific context or setting, or unique historical experiences. This allows for transferability of the results.

\section{Confirmability}

Confirmability refers to the degree the results are neutral and free from bias. Confirmability was addressed by developing an audit trail so the study can be traced or recreated. To avoid bias, the researcher presented his previous experience and qualifications. Three phases of data collection; historical document review, interviews, and observations; were used to triangulate the research findings. The results were also presented to a committee of experts to examine the degree the results were neutral and free from bias.

\section{Data Analysis}

The data were analyzed and categorized after all data was collected. The findings were categorized by sections according to topics discussed. After topics were established, correlations were examined and an overall theme regarding the changes observed was established. The data from all three phases were compared and contrasted. The data were coded and recoded for consistency.

\section{Use of Findings}

The finding of this study can be used to formally document the history and tradition of 4-H camp music in West Virginia. These interviews, sources, and observations look at where we've come from as well as where we're going in regards to how 4-H music is used to impact the lives of youth that attend West Virginia 4-H camps. 


\section{CHAPTER IV}

\section{Findings}

\section{Purpose of the Study}

The purpose of this study was to determine the role of music in 4- $\mathrm{H}$ traditions from the beginning of the organization to the present. In addition to the overall 4-H traditions, the research focused on traditions in the 4-H camping program. The research will examine songs, song quality, and the role they played in the 4-H tradition and/or the 4-H camp experience. Differences and similarities of 4-H music from the beginning of the 4-H program in West Virginia to the present day were explored. The study also examined the origins of the songs used in the West Virginia 4-H program discerning whether or not it was specifically a 4-H original song or a song originally written for different purposes. The study described songs currently being used and those that are no longer used.

\section{Objectives of the Study}

The objectives of this study are reflected in the following research questions:

1. What songs have been traditionally sung in West Virginia 4-H?

2. Why have songs been dropped from the list of songs preferred?

3. What changes have occurred in how these songs have been documented?

4. What are the origins of the songs sung as a part of West Virginia 4-H program?

5. What are the perceptions of 4-H Alumni and Current members of the quality of songs in West Virginia 4-H?

6. Have songs changed musically from their origin to present day?

7. Are there any controversial issues with any songs in West Virginia 4-H? 


\section{Findings}

When asked, interviewees expressed their favorite and least favorite 4-H songs to sing at 4-H camp. Each individual has a favorite and sometimes multiple favorites and least favorite songs for various reasons specific to that individual. It is important to note that during the interviews no one had trouble coming up with favorites and least favorites; rather many found it difficult to narrow down their top choice or to a few choices.

4-H songs can be broken down into many different categories. A simple categorization broke them into fast songs and slow songs. This differentiation is commonly used as a way ECIs decide on which song to use for an upcoming event at evening Council Circle programs.

Many respondents prefer slow songs sung around the campfire or as part of special 4-H candle lighting ceremonies. Other respondents preferred faster pace camp songs that have physical motions and got everyone excited and involved. This song style included rounds, songs with motions, and call and response songs of a fast tempo and style.

Respondents who expressed a preference for slow songs mentioned songs that connected them to their mutual home such as "Come Home to West Virginia" and "My Home Among the Hills.” Other slow songs mentioned as favorites fell into the musical genre of traditional spirituals that have been adapted for 4-H camp. When asked about favorite songs, one interviewee mentioned slow songs with special meaning to her. 
"I love some of the slow songs we sing. I really love “Over My Head.” I think that's a gorgeous song, I love the lyrics to that song "laughter in the air”, “friendship in the air.” I think it’s true, I think nowhere else but 4-H camp can you actually feel laughter in the air and I love that song for that reason. "There Was a Great Conductor" still has meaning for me because I am a conductor and struggle to lead ensembles.

Those who mentioned favorite songs that fell into the "fast" category enjoyed the movement and spirit that corresponded with the songs. Having spent time in many 4- $\mathrm{H}$ camp settings in many different roles, an interviewee provided the following statement about their favorite fast songs.

"You know when I say move a lot I think of ones like "Singing in the Rain" where you're doing different body motions or movements. "Button Factory" song. "Father Abraham," we used to sing it a lot. A lot of people tend to get tired of those like "Alice the Camel," where you're doing the same motion over and over, but at least it gets you active. I think those are some of the more fun ones to sing. And then I think clapping too.

Clapping gets people in the rhythm and people are doing the same thing, clapping can get out of control, but ones when there's a regular rhythm where there's a clap or a stomp. Something that's going to keep people in a rhythm altogether. I think I'm kind of partial to some songs that I feel that I brought to West Virginia 4-H. I went to another conference out of state and they had a version of "Bubblin.” That's a song that I brought 
back and taught the ECIs and it still goes today. People singing the song "We Will Rock You" is one that I've seen somewhere else that I brought in and it has the movements like with the rhythm and getting everybody involved. So I'm kind of partial to those two songs because those are two that I actually brought in and they have some life to them still.

An interesting perspective on this categorization was given by an interviewee who had been a 4-H member, ECI, led songs in many situations at 4-H camps and was a 4-H Extension Agent. When asked for an opinion on fast verses slow songs the response was: I think just a good mixture. Some people probably prefer to sing all fast songs and some people prefer to sing all slow. I think just having a good mixture. Throughout Council Circle I think you should have a blend of all different sorts of songs. I think there are faster songs and slower songs and some that fall kind of in the middle. I'm all about having a diverse set of songs to participate with.

While many songs were known as favorites by $4-\mathrm{H}$ members and alumni, there were also less favored songs. Interview participants were asked not only what their favorite 4-H camp song was but also what their least favorite songs were. Most mentioned songs that are sung too frequently or those with themes for younger children. When asked to talk about their least favorite 4- $\mathrm{H}$ camp song an interview participant responded with... 
Probably the short dumb ones that get used so often like "Grey Squirrel" and "A Boy and a Girl in a Little Canoe." Why does the girl always have to get out and swim? It's stupid. Like the basic songs they would teach at your younger ages.

Another interview offered the following statement:

"Barges.” I guess because nobody ever knows the words. They just know the chorus. And I guess some of the new songs because I'm old school. I don't like some of the newer songs.

4-H camp songs hold special meaning for those who have attended camp. The songs learned and sung in camp are remembered for a lifetime. As unique as each individual that has attended a 4-H camp in West Virginia, the special meanings that are perceived and understood are very special.

A song mentioned multiple times holds special meaning for many 4-Hers. "Come Home to West Virginia" is performed by the chorus class at each state camp. The chorus usually performs this selection as part of an end of camp ceremony. While the key line of the song is "so, come home to West Virginia", a change is made to make it more special to 4-H members who attend camp at Jacksons Mill. On the last time through the chorus the words are changed to “so, come home to Jackson's Mill, come hear the campers' song, you've been away too long.” 
This song remains with those leaving the camp and also with those who may grow and leave the state of West Virginia. When asked about songs with special meaning interviewees replied with:

"Come home to West Virginia" is probably the most meaningful to me. It's always sung the last day of camp and everybody's sad because you have to say goodbye to your friends that you probably only get to see once or twice a year so that's kind of a meaningful thing. Now every time I hear it I think wow, that was when I was defining myself as an individual coming to state camps and branching out and meeting more diverse people and meeting people from all over the state.

“Come Home to West Virginia” has a lot of meaning to me because when I was younger my mom would take my sister and me to camp with her. My family lives in West Virginia but as a child we lived in Pennsylvania so coming to camp was like coming home to West Virginia because we didn’t live there and we were rarely in West Virginia. So to me that song, since I was a very young girl always made me tear up because I had such a wonderful family in West Virginia and such a wonderful core through 4-H but I only got to be a part of it once a year, so for me to come home to West Virginia it was really symbolic, it really was what it was, I wasn't there and I felt so comfortable there with all the people there that it was, it became a really important song to me. 
An interesting perception of individuals who attended county 4-H camp, as well as state 4-H camps, was that they consider many songs to have been originated or created by $4-\mathrm{H}$ when in fact they were written and brought in from other places. The most interesting song that falls into this discussion is "My Home Among the Hills." This song is highly regarded as a special 4-H camp song. The following are thoughts and opinions based on the question what is an example of a 4-H camp song.

When I hear “My Home Among the Hills,” I consider it a 4-H song because that's where I heard it first and that's where it became so important. I didn't say that it was one of the important ones but it is. That and “Come home to West Virginia:” I think those are very important. They create such strong emotions when we come to camp and I think that makes them very important.

“Home Among The Hills," the top choir at WVU struggles with that song sometimes and you know in the right setting at 4-H camp massive groups of kids are singing it well and its beautiful and its mind boggling. I think a big part of it is that we put heart into it. The meaning that it has for us beyond the notes that we're singing. Nobody thinks about that. It's about a song that means a lot to us and we're singing it the best we can.

I consider it a 4-H song because that's kind of where I was, even though I went to West Virginia Wesleyan and that was our song at West Virginia Wesleyan, I still consider it a 4-H song because I think a song originates 
from where it touches your heart the most, where it finds the most meaning.

Songs that are considered by many as “flagship” 4-H camp songs include: “4-H Hymn,” and "Plowing,” and "Dreaming.” Those are your more traditional songs that have been going around for probably 80 years now since 4-H started. "Country Roads," "My Home Among the Hills," "West Virginia Hills.”

When asked which songs were most important to the identity of 4-H camp music an interviewee responded by saying:

I believe identifier songs are really important. So I believe the "H’s Four" is important because it's a song that is sung about who we are. It was written at an interesting time. I actually remember when it was written and was presented as “Here's the New National Song.” And then to me the old traditional one as well, the “4-H Hymn,” which doesn't get used maybe as much because we have to be careful of our separation of religion and state, but the "H's Four" came out, I think in the 70's is what I a kind of remember. So I think the ones that are actually about us are important. I also think songs like “The Rhododendron Song," "West Virginia Hills," “My Home Among the Hills,” are songs that when I hear them, they bring back memories because I haven’t always had the opportunity to live in West Virginia my whole life because of work. I've lived out of the state for many years. Those are the great songs that are about home. I think that sense of home, that sense of belonging works for all 4-Hers in our 
program. Then along that line, the songs that are important are the ones that contribute, or add to, like "Come Home to West Virginia" is a new one that was written recently, but it fits right there with that other set.”

The 4-H motto is "To make the best better." As a part of the interviews participants were asked questions inquiring as to which songs were most important to our traditions, which songs should be kept, and which songs should be changed or no longer used. Interviewees shared some great insight into how we can make our 4-H camp music even better by keeping things we do well and changing or altering things to enhance 4-H camp music. When asked, "Which songs do you feel are most important to our tradition?” the following responses were given:

“West Virginia Boys and Girls,” the tribal songs, “My Home Among the Hills," "Come Home to West Virginia"

I think the state songs, like the state girl... "Plowing" and "Dreaming." Even though we don't sing them very often I still think those are important. Like “West Virginia Boys and Girls,” even though I don’t like it, I still think it's important. The songs that are sung at Council Circle at certain points, those are really important.

"Brightly Beams," and then like the final Council Circle ones "Pass It On,” the "4-H Hymn,” the " $H$ 's Four," that's one of my favorites also. I 
love during the OMC banquet when everyone sings it and when you stomp on the floor in the dining hall, it gives me cold chills every time. Singing is what makes camp. You have your tribal meetings and Council Circle wouldn’t be Council Circle without songs. Assembly wouldn’t be assembly without the camp song we do every year. Any downtime between speakers or downtime between events that go on we sing songs. Probably one of the two or three core things that makes 4-H.

I think definitely those historical ones that I was referencing like "West Virginia Boys and Girls," "Plowing,” "Dreaming,” "H’s Four.” I think those songs, and there are probably some more that I'll think of, have historical relevance. The Tribal Songs. We had to re-evaluate those a few years ago to make sure those were correct and appropriate. Those were songs that were written $40,50,60,70,80,90$ years ago that really stick to the traditions of 4- $\mathrm{H}$ and really the founding fathers of 4- $\mathrm{H}$ so I think those are important. I think it's important to know why we sing them and what it is. Sometimes that can get lost too. I think those are appropriate. As far as some of the fast and slow ones that aren't as much what I would label traditional 4-H songs I think those are important but again I think it’s kind of cyclical. They'll come and go. If we’re singing “Pizza Man” now, if we don't sing it in 30 or 40 years it isn't that big of a deal. I don't know. It might be. I'm sure there are fast and slow songs 50 years ago that we don't 
sing now. I think really those ones that stick to the 4- $\mathrm{H}$ traditions are the ones that are important to keep and maintain and really educate about. Definitely I think "My Home among the Hills" because it represents West Virginia and I think it is very connected to this program even though it really connected to West Virginia. I was thinking of "So Come Home Come Home to West Virginia" and you know there's a verse about Jackson’s Mill.

I think the ones that if you've had several generations that have been in the camping program, for example, grandma and mom and kid all say, 'well I sang that one.' I think any tradition you hand down makes an experience one that's more bonding for groups and people identify even stronger with the program or the activity. So I think that those traditional songs that we've sang for years are very important. I also think it's very important to change it up. So I love it when someone brings a new song to the program because there's that unexpected. I also love the way that we use music in a parody. We do an awful lot of 'we're going to sing a song about a particular thing' so we borrow a tune, and we change the words, so I think that's a neat activity for people to do. I think that's another important part of our tradition. 
Respondents provided their perspectives on the continuation of 4- $\mathrm{H}$ camp music programming and how state 4-H camp events are used as a "measuring stick" for county 4-H camps.

Yeah, and that's probably because I didn't grow up in a county, I grew up in state 4-H, that was my camp. That's probably why I see it that way, but at the same time that's the only unity we can find. I'm not saying, I don't think that the county camps should give up their individuality; I think it’s great that everybody has a different twist. But I do sort of measure the differences by what happens at state 4-H camp and the songs sung there just because that's everybody from all over the state coming together there.

I guess back to what we were talking about earlier was finding a way whether it be through ECIs or camp training or different things like that of better training those who are leading so that we pass things down in a way that is correct and understandable. I think that's one of the areas where we lack. I think it gives people the opportunity to say that may never jump out there in front of a group and sing a song I think it promotes that but I think that we have to improve on our leadership and understand that in the job responsibilities of being an ECI that has to be something that's really important and has to be something that's really looked at. We still have to hold true to the camping traditions of those songs especially when it comes to those traditional songs because not every 4-Her in the state is 
going to have the exposure that they get from that rich musical experience at the state level. They get what you find at county camps and we don't always have that leadership in those county camps so that's why we send those people out there to do that job and I think that's one of those things that's not focused on as much as it probably should be.

I guess it would be that we just keep singing especially in Council Circle, I think the best music we make is in Council Circle. I mean, you know, even acoustically, it’s an amazing experience to sing in a circle like that where all of our voices come together and we can hear everyone around us. I think it's important that we keep making music a focus during Council Circle as well as throughout the day. At state camp we don't do it during the day nearly as much as they do at county camps. I might bring that back a little more so we have more opportunities to sing, but I think in general I would say keeping the, I don't want to use the word “sacred” but sacred time of Council Circle for music and the importance that it is there.

I think a lot of people would say we'd like to sing more. There are opportunities during the day to sing. You can sing before meals, you can sing at Council Circle, you can sing before assemblies and that sort of stuff. I think a lot of people feel like there ought to be more opportunity to sing songs. That's something that we try to do in Harrison County at younger camp. We have a half hour devoted every day just to sing songs 
and learn traditional ones and sing new ones. That's something I think we do to help with that. If there were chances to sing more and chances to help people learn more that's always good. I think there’s another common complaint when you get into some of these songs people don't know the words and they just clap and they yell and they scream. I think clapping and yelling and screaming is appropriate for the right song at the right time. I think sometimes it gets overboard. People just scream out parts that they know and they don't know the other words to the song. I don’t think screaming out parts that you know is necessarily bad but I don’t think you should do it just because you don’t know any other part of the song. I think maybe just an overall better knowledge.”

Our traditions are such because they’ve been passed on year after year, song after song. Each year at the beginning of a week of camp, the songs are taught and campers start singing. By the end of the week you have an entire camp singing songs together and building musical memories that last a lifetime. When asked about how our music is passed on, a response was.

Just aural traditions. I don’t think we're good about... we actually had a visitor a few years to the West Virginia camping program, she’s like "I want to learn these songs, I want to teach them to my children, give me your song books.” Well it's not like we have this treasure trove of song books that we can go to the song vault and hand you these books and this 
will have everything you need, because we pass on so many of the songs just through oral tradition.

Do you find it important? Do you think we need song books? I think, yes. Even if just for recording purposes. Like to have it written down somewhere. I don't think we should start passing out songbooks to all the campers and have them carry them around and do our songs out of books. I don’t think that should be the way it is. I think a great deal of why our music is so powerful is because it is oral. If you put a song book in front of them it makes it way less fun, and way more work. At the same time for the songs like the tribal songs and the "West Virginia Boys and Girl's Song" we need to have accurate notation of the melodies and stuff so it doesn’t die with a non-musical generation. Maybe not die, but suffer. Because we keep passing it on, eventually it will be nothing like it began, and I think a song that's so important to our heritage we need to hold on to it in the original form.

I think so, and I think the time where we lost continuity with the camp workers... the ECI's, and I think now we probably need to record them or something so that people get those melodies firmly back in their brains. When it comes to the other songs it's kind of mix. Some stuff you'll hear a different way, but then I've always heard that to a certain extent. Being in Maryland's Extension system, they did some singing, and the same song 
we would've been singing in West Virginia, they might sing with a slightly different verse, or a different melody. I think that's because these are those handed down traditions. We don't usually sit there with the sheet music like a choir.

A special song was written at Jackson's Mill during Older Members Conference. The following is an account of how this song came to be. There was a guy. I think his first name was Larry. He was a professional song writer and he came around while we were in discussion groups and asked people what does the Mill mean to you? What does your experiences mean to you here? A lot of us said well Jackson’s Mill is like a second home to me. And I like the history about Stonewall Jackson and here. And I feel safe here. And if you listen to the song all of those are incorporated in “Going Home to Jackson’s Mill.” It talks about where Stonewall Jackson stood like a stone wall and there's some other elements that every camper had input in. He took everybody's advice and he sat down with a core group of people and composed the music. Put the words to the music, copyrighted the song.

I was probably 17 or 18 halfway through my OMC life and I was in one of the groups that he came and talked to. When we wrote it, I was one of the first two or three people to play it in front of everybody. 
He came in on a Monday or a Tuesday For the first two or three days he talked to all the people. Later in the week he had some music and wrote out the verse and the chorus. A group got together and he showed us the whole rhythm and all that stuff. Five of us had guitars and that's just how it came together. It wasn’t copyrighted that week but we came back a year later and it was copyrighted.

We did play it too during my 21 year old year and it's sad you don't hear it much anymore. I hear it maybe once a year.

When asked about songs of poor quality or ways 4-H camp songs are sung poorly, thoughts included...

I think it encourages the kids to just scream and I think we've lost a lot of the melodies in some of our camp songs. Some camp songs have beautiful song melodies and we don’t even know because everyone just screams and that's one of the ones that encourage it and it's just the same thing over and over again and it’s not incredibly rhythmic and there isn’t really a theme. It's just screaming for the sake of noise.

I don't like the current trend in 4-H songs where they don't seem like songs to me, they seem like shouting. I don’t know that I can name a specific one, maybe you can give me some names of some of them. I like the creative ones, like "Ratlin Bog” and some of those kind of things, but I 
don't really like the songs that truly don't seem like songs to me, there's just more.... Or sometimes it’s the way people do certain songs. Like I love, "If I Had a Hammer.” I like the original way it was, then I like what we would call the Craig Presar style of doing it, but them some people come in and just shout it, and talk it instead of do it, so it’s basically those least favorite ones are those that people are shouting and it's really shouting, call and response, and not really singing.

I think we need fun songs, and I love having new songs, but what I don't like is when songs lose their tunes. When people just start shouting. I guess those are fun, but when you're losing the music to all of your songs because everyone is just shouting the words, no one is learning them.

Throughout the history of 4- $\mathrm{H}$, songs have been added and removed from the camp music repertoire for various reasons. Recently, songs with certain religious connotations or Native American imagery have been prohibited or have fallen into disuse.

"I know there’s a couple Native American type songs. A lot of times you would sing “One Little, Two Little, Three Little Indians.” That’s not appropriate. "Indian Braves are High Minded.” That was another song we used to sing and it's not appropriate. Some of the religious ones are still around and in my opinion they're not overly religious. They reference God or reference something like that but I think some of those are sung a little 
more cautiously. The “Grace” song is one. In camps before every meal and everyone would sing the "Grace” song. It actually happened I think when I was a camper or started as a counselor, the move to sing "Simple Gifts” at camp as kind of a neutral meal time song which I agree with. At Harrison county camps my preference is to sing “Simple Gifts” first. Some people continue to sing the “Grace” song which I don’t promote. I don’t discourage it. If they want to do that they can do that. My thought is not everybody in that room or building maybe has the same religious beliefs so I think we should just stick to the one that's kind of neutral. There are a few songs like that that I think have gone away, but I think they've gone away for the right reasons.

“Dem Bones” depending on the county you have to be careful about that because it is the story about Adam and Eve. You don't know if they sing it strong there. Because in the southern part of the state let's face it they're still very strongly Christian based. Sometimes there is no diversity in that county and it's acceptable to just have that song. And in some counties they say oh it's more of a story, less of the religious but they still touch it because of legality reasons. Other songs that I can think of that we don’t sing anymore is the "Indian Braves" because that touched on racism and that went with our 2003 controversy of the Indian use of all the things. It's similar to what happened with the mascots in college sports. I remember that one because I really liked it as a kid and it's no longer there. Also the 
Minnie's bloomers, whichever one has the Chinese racism song. “Teenie Weenie Housie" song. That one because of the racism against Chinese people. Songs are songs. Those are some I can think of off the top of my head. A lot of great songs have just died because kids don’t know them anymore. Kids I guess and ECIs don't know them anymore. The ones who are supposed to take songs to certain counties. The singing is one of the biggest things for camping instructors. It’s a great advantage.

Do you recall songs that used to be sung that aren’t anymore? Yes. Many of the songs that are focused on faith. Other songs have been taken out of the program because they were inappropriate.

Council Circle observations were made at various state and county 4-H camps. Song leaders of wide ranges of ability and experience were observed. As a part of all Council Circles observed, “As the Bright Flames” was sung prior to lighting the campfire, as well as "Brightly Beams" was sung before the closing dismissal. Songs varied in style based on mood and flow of Council Circle. Both females and males served as song leaders as well as councilors, ECI's, and campers. Spirited singing was always the case. Most all knew the words and participated in the group singing and music. It is important to note that the observations we made as a participant of the Council Circle program. 


\section{CHAPTER V}

\section{Summary, Conclusions, and Recommendations}

\section{Purpose of the Study}

The purpose of this study was to determine the role of music in 4- $\mathrm{H}$ traditions from the beginning of the organization to the present. In addition to the overall 4-H traditions, the research focused on traditions in the 4-H camping program. The research will examine songs, song quality, and the role they played in the 4-H tradition and/or the 4-H camp experience. Differences and similarities of 4-H music from the beginning of the 4-H program in West Virginia to the present day were explored. The study also examined the origins of the songs used in the West Virginia 4-H program discerning whether or not it was specifically a 4-H original song or a song originally written for

different purposes. The study described songs currently being used and those that are no longer used.

\section{Objectives of the Study}

The objectives of this study are reflected in the following research questions:

1. What songs have been traditionally sung in West Virginia 4-H?

2. Why have songs been dropped from the list of songs preferred?

3. What changes have occurred in how these songs have been documented?

4. What are the origins of the songs sung as a part of the West Virginia 4-H program?

5. What are the perceptions of 4-H Alumni and Members of the quality of songs in West Virginia 4-H?

6. Have songs changed musically from their origin to present day? 
7. Are there any controversial issues with any songs in West Virginia 4-H?

\section{Summary}

Because of the important place music holds in society, 4- $\mathrm{H}$, and 4-H camps it is important to understand the songs used to enhance 4-H camps in West Virginia. This study takes an objective look at past and current West Virginia camp songs and how they are used in 4-H camps. Having documentation of the songs, song styles, traditions, and practices involved in West Virginia 4-H camps allows us to preserve and improve those traditions. The interviews, field observations, and song books observed all help to paint the picture of the rich traditions and heritage present in West Virginia 4-H camp music.

4-H songs are can be broken down into many different categories, one of which is fast or slow. 4-H participants each have their own favorites and least favorites. A mix of fast and slow songs is used in the various settings during 4-H camp. Songs sung at camp often have special meaning shared by those who attended and participated in that camp. The songs become associated with special ceremonies of aspects of $4-\mathrm{H}$ camp. Council circle campfire programs, charting and all-star pin wearer's ceremonies, candle lighting, and many other ceremonies are identified with certain songs.

Songs such as, “My Home Among the Hills," "Come Home to West Virginia," “West Virginia Boys and Girls," “Country Roads,” "Simple Gifts” and many others share a common theme of being about or from West Virginia. Many 4-H participants find these songs to be meaningful because of their ties to the state in which they are from. While songs such as “West Virginia Boys and Girls” were written for the West Virginia 4-H program, other such as "My Home Among the Hills” was not. 
4-H songs are taught and learned from a variety of sources. Each camp has a different way of teaching songs and passing on the traditions unique to that camp and setting. From a state level standpoint, those barometer for measurement are the three state 4-H camps at Jackson’s Mill and the ECI’s who take songs from their training around to all the county camps. 4-H songs are revived regularly from disuse as well as new ones made up or pulled from various sources each year. Many people see this as a key aspect and way to keep tradition while also keeping the music fresh, new, and appealing. Observing Council Circles at various camps at both the state and county level showed that participation and atmosphere correlate with the song leader's ability and enthusiasm. In the West Virginia 4-H camping system, song leaders can be any number of individuals in the camp setting. ECI's, camp staff, volunteers, and campers all regularly serve in a role as a song leader. Their prior knowledge, experience, vocal/musical ability, enthusiasm all add to the equation when songs are being led. One can gain skill and competency to become a better song leader by simply leading songs when given the opportunity.

Many songs have changed styles over time. A key example of this is "If I had a Hammer" which is a folksong performed by Peter, Paul, and Mary, as well as how it is performed in 4-H currently to the tune of “La Bamba," made famous by Craig Presar. Because Craig put his own spin on an already popular song, it is still sung that way today by hundreds who don't even know that's not how it goes.

Many songs have fallen into disuse for various reasons. It is important to note that one of those reasons is political correctness/religious affiliation. While many 4-H songs were hymns in the beginning of the 4-H program, songs with connection to specific 
religious beliefs are no longer lead. Likewise, songs with reference to a specific race or people are no longer sung.

Songbooks differ widely in style and content. Songbooks from different sources provide very different documentation of 4-H camp songs. The most common songbook is one that only has titles and words without written notation. Older songbooks still have written music with notation which comes from the tradition of singing hymns in 4-H camp. Many different counties have produced their own songbooks with specific songs that set that county apart. 4-H Extension Agents usually include song lyrics in camp programs as a way to help kids learn and remember standard songs sung every day.

\section{Conclusions}

Without camp songs and music 4-H camps would not be as special or memorable. 4-H camp music in West Virginia has key components recognized by its participants and alumni. The ability to set the mood for various events and ceremonies associated with the special time that is $4-\mathrm{H}$ camp leaves a lasting impression on its participants. Based on the interview responses, all mentioned the importance of singing and its place alluding to the fact that without camp songs and music camp would not be as special or memorable. 4-H camps in West Virginia are a very special place for youth to learn and grow and our camp songs are the soundtrack to that time in the memory of thousands of youth who have attended throughout the years.

4-H musical traditions must be preserved. The importance of preserving these traditions was reflected in all three phases of this study. There are not consistent songbooks thoroughly documenting our songs. Evaluation of state and county 4- $\mathrm{H}$ camps music programming and implementation is unclear. The capacity of our 
preserving the traditions of these songs rests primarily on the continuation of passing on through oral tradition along with documentation in the form of song books.

Many 4-H songs did not have their origins in 4-H. A fascinating aspect of this study is the notion of "what is a 4-H song?" Based on interview responses, 4- $\mathrm{H}$ songs are simply songs we sing at 4-H camp. This gives little regard to the actual origin of any of the songs being sung. 4- $\mathrm{H}$ camp participants associate the songs they sing with the experience in a way that transforms the song into a 4-H song. A premier example of this is "My Home Among the Hills." This song was originally written by E.W. James and is sung and performed many places, including 4- $\mathrm{H}$ camp. Yet, because we sing that song as a special song usually performed by the camp chorus as part of ceremonies, it is a $4-\mathrm{H}$ song.

Singing is a very important part of the 4-H camp experience. No one song is bigger than the 4-H camp program. It is not the notion of what song is being sung, rather it is the notion that we always continue to sing. Songs come and go, change and stay the same while the importance of singing stays constant. The association made with 4- $\mathrm{H}$ camp and singing songs at 4- $\mathrm{H}$ camp is a very strong one that lasts a lifetime.

Song leaders have a significant influence over the quality of music in a 4-H camp setting. At a basic level, they lead the song and the success of each instance of a song being lead is based primarily on the song leader's abilities. While the song leader is not solely responsible for a successful song experience, they are leading the campers in singing. It is important to have experienced and talented song leaders to allow for the best quality of music possible. Many memories from those interviewed describe the quality of music they heard during a ceremony or event at a 4-H camp. Quality music is 
an important part of West Virginia 4-H camp and the lasting memories that many have are a tribute to those who lead and performed songs well.

4-H participants and alumni have strong ties to their local community, state, and region. West Virginians are a special people and West Virginia 4-Hers are proud of their state and local communities. This ownership is taught through the 4-H program and is reflected in the 4-H pledge: I pledge my Head to clearer thinking, my Heart to greater loyalty, my Hands to larger service, and my Health to better Living, for my club, my community, my country, and my world. This is very evident when interviewees were asked to share their favorite song(s) and many of those were songs about or from West Virginia. Songs such as “Country Roads," “Come Home to West Virginia," "My Home Among the Hills" were all mentioned multiple times as favorite 4-H songs. The fact that they instill a sense of state and local pride along with a pride in 4- $\mathrm{H}$ camp and the 4-H program are very unique. This special circumstance adds to the importance of the singing traditions in West Virginia 4-H camps.

\section{Recommendations}

To preserve the traditions of 4-H camp music, an up to date song data base could be created that could be easily accessed by county 4-H extension agents for use in 4-H camps. Both quantitative and qualitative studies could be done to further document the current trends as well as historical aspects of the subject. Observations of West Virginia 4-H camps could be made and compared to observations from other national and regional 4-H camps. 


\section{REFERENCES}

Ary, D., Jacobs, L. C., Razavieh, A. (2006). Introduction to research in education. NewYork: Holt, Rinehart and Winston.

Catterall, J., Chapleau, R., \& Iwanaga, J. (1999). Involvement in the Arts and Human Development:. Los Angeles: University of California .

Etzler, C. A. (Ed.) (1970). West Virginia Sings, Delaware, OH: World Around Songs, Inc.

Foundation, L. M. (2011, August 4th). Who Is Lowell Mason. Retrieved from http://lowellmasonhouse.org/

Gibson, J. (2002, November). A History of Musical Education in America During the Antebellum Period. Retrieved from http://mgagnon.myweb.uga.edu/students/Gibson.htm

Girl Scouts of America. (2011, October 24). Music. Retrieved from http://girlscouts.org/program/gs_central/arts/music.asp

Hatch, R. E.. (Ed.) (1946). West Virginia Sings, Delaware, OH: World Around Songs, Inc.

National 4-H Council. (2010). National 4-H Enrollment Report. Retrieved from http://www.reeis.usda.gov/discoverer/app/grid?event=displayData\&stateStr

National 4-H History Preservation Team. (2011). 4-H songs and music. Retrieved from http://4-hhistorypreservation.com/Music/

Stewart, G. H. (1969). A Touch of Carisma. Morgantown, West Virginia: West Virginia 4-H All Stars.

Thibodeaux, W. (2011). Concise history of American music education. Retrieved from http://www.ehow.com/about_6190707_concise-history-american-musiceducation.html

Turner, R. A. (Ed.), National 4-H Club Song Book, Winona Lake, IN: Rodeheaver Co..

West Virginia Sings. (1967). 1967. Delaware, Ohio: World Around Songs.

West Virginia University. (2010, February 3). Extension's 4-H Youth Development Program History. Retrieved from http://4-hyd.ext.wvu.edu/about4h/history

WVU Extension Service. W. V. (2003, May 5). Responsible Use of Native American Themes in West Virginia 4-H. Retrieved http://4hyd.ext.wvu.edu/r/download/94986 


\section{SONGS CITED}

American Folk Song. (1970). Down in the Valley. In Etzler, C. A. (Ed.), West Virginia Sings, Delaware, OH: World Around Songs, Inc.

Buchanan, F. R. \& Parish, R. M. (1970). Dreaming. In Etzler, C. A. (Ed.), West Virginia Sings, Delaware, OH: World Around Songs, Inc.

Author unknown. (n.d.) Father Abraham

Miller, H. H. \& Douglas, S. H. (1970). Follow the Gleam. In Etzler, C. A. (Ed.), West Virginia Sings, Delaware, OH: World Around Songs, Inc.

Author unknown. (1970). Grace Song. In Etzler, C. A. (Ed.), West Virginia Sings, Delaware, OH: World Around Songs, Inc.

Author unknown. (n.d.) Grey Squirrel

Etzler, C. A. (1970). H’s Four. In Etzler, C. A. (Ed.), West Virginia Sings, Delaware, OH: World Around Songs, Inc.

Brewster, B. M. \& Kelley, D. E. (1970). Home on the Range

Hays, L. \& Seeger, P. (1970). If I Had a Hammer. In Etzler, C. A. (Ed.), West Virginia Sings, Delaware, OH: World Around Songs, Inc.

Author unknown. (1970). Indian Braves are High Minded. In Etzler, C. A. (Ed.), West Virginia Sings, Delaware, OH: World Around Songs, Inc.

Author unknown. (n.d.) Jacob's Ladder

Author unknown. (1970). Mingo Tribal Song. In Etzler, C. A. (Ed.), West Virginia Sings, Delaware, OH: World Around Songs, Inc.

James, E. W. (1970). My Home Among the Hills. In Etzler, C. A. (Ed.), West Virginia Sings, Delaware, OH: World Around Songs, Inc.

Smith, F. S. (1970). National 4-H Pledge Song. In Etzler, C. A. (Ed.), West Virginia Sings, Delaware, OH: World Around Songs, Inc.

Baring-Gould, S. \& Barnby, J. (1970). Now the Day Is Over. In Etzler, C. A. (Ed.), West Virginia Sings, Delaware, OH: World Around Songs, Inc.

Author unknown. (n.d.) One Little, Two Little, Three Little Indians

Author unknown. (n.d.) Over My Head

Kiser, K. (1969) Pass It On 
Buchanan, F. R. \& Parish, R. M. (1970). Plowing Song. In Etzler, C. A. (Ed.), West Virginia Sings, Delaware, OH: World Around Songs, Inc.

Author unknown. (n.d.) Ratlin Bog

Author unknown. (1970). Seneca Tribal Song. In Etzler, C. A. (Ed.), West Virginia Sings, Delaware, OH: World Around Songs, Inc.

Shaker Hymn. (1970). Simple Gifts. In Etzler, C. A. (Ed.), West Virginia Sings, Delaware, OH: World Around Songs, Inc.

Freed, A. \& Brown, N. H. (1929) Singing in the Rain

Negro Spiritual. (1970). Study War No More. In Etzler, C. A. (Ed.), West Virginia Sings, Delaware, OH: World Around Songs, Inc.

Negro Spiritual. (1970). Swing Low Sweet Chariot. In Etzler, C. A. (Ed.), West Virginia Sings, Delaware, OH: World Around Songs, Inc.

Author unknown. (n.d.) Teenie Weenie Housie

Author unknown. (1970). Tell Me Why In Etzler, C. A. (Ed.), West Virginia Sings, Delaware, OH: World Around Songs, Inc.

Priestly, A. M. \& Goldman, E. F. (1970). The Pride of the Land. In Etzler, C. A. (Ed.), West Virginia Sings, Delaware, OH: World Around Songs, Inc.

Author unknown. (1970). The Rhododendron Song. In Etzler, C. A. (Ed.), West Virginia Sings, Delaware, OH: World Around Songs, Inc.

Key, F. S. \& Smith, J. S. (1946) The Star-Spangled Banner. In Turner, R. A. (Ed.), National 4-H Club Song Book, Winona Lake, IN: Rodeheaver Co.

Author unknown. (n.d.) There Was a Great Conductor

Babcock, M. D. \& Shepard, F. L. (1970). This is My Father's World. In Etzler, C. A. (Ed.), West Virginia Sings, Delaware, OH: World Around Songs, Inc.

May, B. (1977) We Will Rock You

Rouzer, P. C. \& Shipman, B. R. (1970). West Virginia Boys and Girls. In Etzler, C. A. (Ed.), West Virginia Sings, Delaware, OH: World Around Songs, Inc.

King, E. \& Engle, H. E. (1970). West Virginia Hills. In Etzler, C. A. (Ed.), West Virginia Sings, Delaware, OH: World Around Songs, Inc. 
VITA

\section{Jason Burnside}

PO BOX 172

Hepzibah WV, 26369

\section{EDUCATION:}

West Virginia University: Morgantown, WV

Masters of Science in Agriculture and Extension Education

Alderson Broaddus College: Philippi, WV

Bachelor of Arts in Music Education
Davis College of Agriculture

December 2011

May 2009

\section{EXPERIENCE:}

West Virginia University Graduate Assistant

WVU Hospitals Wellness Program
August 2010- Present Morgantown, WV

Supervisor: Debbie McDonald, State 4-H Leader, (304) 293-2796

Assist the 4-H program in all areas. Attended and assist with professional development training. Teach and assist with Essential Elements training statewide. Assist in training and work with Extension Camping Instructors in summing 4-H camp programs. Conduct 4-H and youth development research and evaluations. Assist county agents with county programming in schools and summer camp.

Extension Camping Instructor (ECI) West Virginia University Extension Service Supervisor: Debbie McDonald, State 4-H Leader, (304) 293-2796 Counselor and activity director at county 4-H camps throughout the state of West Virginia. Duties included planning and directing games and recreation, teaching classes, conducting assemblies, leading and teaching songs, conducting evening campfire programs, maintaining organization of the camp and conflict resolution.

\section{AmeriCorps VISTA}

Sept 2009- August 2010

Harrison County 4-H

\section{Supervisor: Brent Clark, Harrison County Extension Agent}

Served as the afterschool program coordinator teaching 4-H curriculum at 4 after school sites in Harrison County schools. Assisted with all other aspects of the county 4-H program.

\section{OTHER WORK/TEACHING EXPERIENCE}

- Student Teaching at Robert C. Byrd High School, Wind, Jazz, and Percussion Ensembles, 2009

- $\quad$ Student Teaching at Nutter Fort Elementary, Grades 3-5 General Music, 2009

- Bandland Private Trumpet Instructor, Clarksburg WV, 2007-2009 